\title{
Height and weight progression patterns in Mexican children aged between 6 and 12 years and differences with Ramos-Galván growth charts 40 years later
}

\author{
Aldo Ferreira-Hermosillo, ${ }^{1}$ Ivonne Roy-García, ${ }^{2}$ Rodolfo Rivas-Ruiz, ${ }^{2}$ Juan José Palacios-Butchard, ${ }^{3}$ \\ Moisés Mercado ${ }^{1}$ and Juan O. Talavera \\ ${ }^{1}$ Instituto Mexicano del Seguro Social, Centro Médico Nacional Siglo XXI, Unit of Endocrine Disorders Medical Research; ${ }^{2}$ Instituto Mexicano del \\ Seguro Social, Centro Médico Nacional Siglo XXI, Medical Research Training Center; ${ }^{3}$ National Physical Activation Program "Ponte al 100"; ${ }^{4}$ Centro \\ Médico ABC, Department of Teaching and Research. Mexico City, Mexico
}

\begin{abstract}
Introduction: Children and adolescents weight and height are a reflection of the health status and socioeconomic development of a population. Objective: To evaluate height and weight progression patterns of Mexican children and compare them with Dr. Ramos-Galván growth charts 40 years later. Method: Cross-sectional survey conducted on the population of the National Physical Activation Program "Ponte al 100", which includes boys and girls aged six to 12 years. Results: 43,670 boys and 44,103 girls were assessed, stratified by gender and age. The height progression pattern between six and 12 years was $21 \mathrm{~cm}$ in males and $22 \mathrm{~cm}$ in females, whereas the weight progression pattern was 9.86 and $10.05 \mathrm{~kg}$, respectively, for males and females. The proportion of six- and 12-year-old boys who were overweight was 11.2 and $9 \%$, while 14.7 and $15 \%$ were obese. The proportion of six- and 12-year-old girls who were overweight was 8.2 and $9.1 \%$, whereas 21.7 and $13.3 \%$, respectively, were obese. When the obtained values were compared with those of Dr. Ramos Galván growth charts for boys and girls, the average difference was $2 \mathrm{~cm}$. Conclusions: No secular height or weight increase within the last 40 years was documented.
\end{abstract}

KEY WORDS: Weight. Height. Growth charts. Growth. Secular height increase.

\section{Progresión de talla y peso en niños y niñas entre los 6 y los 12 años y su diferencia con las tablas de Ramos Galván 40 años después}

\section{Resumen}

Introducción: El peso y la talla de niños y adolescentes son un reflejo del estado de salud y desarrollo socioeconómico de la población. Objetivo: Evaluar las progresiones de talla y peso de niños y niñas mexicanos y compararlas con las tablas del doctor Ramos Galván a 40 años de distancia. Método: Encuesta transversal realizada en población del Programa Nacional de Activación Física Ponte al 100, que incluye niños y niñas de seis a 12 años. Resultados: Se evaluaron 43670 niños y 44103 niñas, que se estratificaron por sexo y edad. La progresión de talla entre los seis y 12 años fue de $21 \mathrm{~cm}$ en hombres y de $22 \mathrm{~cm}$ en mujeres; la progresión de peso fue de 9.86 y $10.05 \mathrm{~kg}$, respectivamente para hombres y mujeres. La proporción de niños de seis y 12 años con sobrepeso fue de 11.2 y 9 \% y con obesidad, de 14.7 y $15 \%$. La proporción de niñas de seis y 12 años con sobrepeso fue de 8.2 y $9.1 \%$ y con obesidad, de 21.7 y $13.3 \%$, respectivamente. Al comparar los valores 
obtenidos con los de las tablas del doctor Ramos Galván para niños y niñas, el promedio de diferencia fue de $2 \mathrm{~cm}$. Conclusiones: No se documentó un incremento secular de la talla ni del peso en los últimos 40 años.

PALABRAS CLAVE: Peso. Talla. Tablas de crecimiento. Crecimiento. Incremento secular de la talla.

\section{Introduction}

While modernization and globalization in developing countries is partly responsible for social and economic problems, it has also brought significant improvements in the quality of life such as increased access to and distribution of food, urbanization, education and health, which have resulted in a reduction in children morbidity and mortality and nutritional improvement. ${ }^{1-4}$ Portugal refers a height increase of $5.7 \mathrm{~cm}$ in 40 years, ${ }^{5}$ and in some Latin American countries there has been a $9-\mathrm{cm}$ increase in final adult height. ${ }^{67}$

Medical care of the healthy child is based on the monitoring of height and weight. In Mexico, the last height standardizations were carried out by Dr. Ramos-Galván in 1975, with a predominance of children from Mexico City, who had great nutritional advantages in relation to the rural population. ${ }^{8,9}$ Similarly, the height and weight charts of the Centers for Disease Control (CDC) of the United States, published in 2000, have been recommended. ${ }^{10}$ The purpose is to have updated parameters for the follow-up of the healthy Mexican child and to determine whether in the Mexican population there has been an increase in height over the last 40 years, considering rural and urban areas. $^{11,12}$

\section{Methods}

The present study is a secondary analysis of Ponte al $100,,^{13}$ a national intervention program carried out in elementary and secondary public schools in Mexico, where a regime of physical exercise and diet is individually prescribed. An informational meeting is held at each participating school, voluntarily attended by students, parents and teaching personnel. Teachers who agree to participate as evaluators take a course where they are instructed on the use of anthropometric and functional capacity measurement techniques, as well as on the recording of data in a computer platform. Students whose parents or legal guardians agree to participate by signing the corresponding informed consent document undergo an initial evaluation that includes the following:
- Registration of demographic data (age, gender, place of origin and residence).

- Anthropometry and body composition (weight, height, body mass index, percentage of body fat and lean mass, waist, hip and arm circumference).

- Motor fitness (muscular strength and flexibility of the arm, leg and abdomen).

- Musculoskeletal fitness (balance, speed and agility).

- Cardiorespiratory fitness (maximum oxygen consumption during a $20-\mathrm{m}$ run test).

- Neuropsychological fitness (memory and attention assessed by a standard memory challenge test).

So far, the program has enrolled more than one million children and adolescents, and data on the outcome of the nutritional and exercise intervention are currently being analyzed. For this study, demographic and body composition data taken during the initial evaluation were used. Children with any known disease were excluded, as well as those who chronically used medications, or who were in a special nutrition program or who showed any alteration in the measurement of vital signs at rest, which, in that case, were referred to the local health center to receive medical attention.

Height in the standing position was measured with a portable stadiometer in accordance with standard anthropometric guidelines, with the participant standing in the Frankfurt plane. Total weight and body fat percentage were determined by bioelectrical impedance analysis (Tanita UM-081 ${ }^{\circledR}$, Tanita International Division, UK). The body mass index was calculated using the weight/size formula. ${ }^{2}$ These data are stored in a computer platform where each participant can only access their own data through a username and password. Only members of the Ponte al 100 team have access to the data of all participants, in compliance with the confidentiality laws.

The Ponte al 100 project was approved by the Research and Ethics Committee of the American British Cowdray Medical Center of Mexico City.

Mean height and weight for each age group were calculated with their standard deviation and range. Based on these values, growth curves for gender and age were generated. Finally, the height for gender means were compared with those recorded in the charts created by 
Dr. Ramos-Galván in 1975 and the CDC charts of 2000 using a network meta-analysis for cross-sectional studies,$^{14}$ for weighted means with random effects; the Cochrane Collaboration RevMan 5 program was used. The results were represented using forest plots with mean differences and $95 \%$ confidence intervals.

\section{Results}

Anthropometric data of 43,670 boys and 44,103 girls aged between six and 12 years were analyzed. Tables 1 and 2 show the mean values of height in meters (Fig. 1), weight in kilograms, body mass index (BMI), fat percentage, waist circumference in $\mathrm{cm}$ and the classification in overweight and obesity according to the CDC criteria.

The progression of height from six to 12 years was $21 \mathrm{~cm}$ in males $(1.20 \pm 0.10$ to $1.41 \pm 0.07)$ and $22 \mathrm{~cm}$ in females $(1.19 \pm 0.11$ to $1.41 \pm 0.07)$. The progression of weight was $9.86 \mathrm{~kg}$ in males $(25.62 \pm 6.87$ and $35.48 \pm 7.33)$ and $10.05 \mathrm{~kg}$ in females $(25.42 \pm 6.63$ to $35.47 \pm 7.56$ ). BMl progression was $0.8 \mathrm{~kg} / \mathrm{m}^{2}$ in males $(17.1 \pm 2.7$ to $17.9 \pm 2.8)$ and $0.4 \mathrm{~kg} / \mathrm{m}^{2}$ in females $(17.4 \pm 3.4$ to $17.8 \pm 2.8)$.

The percentage of body fat ranged from $16.03 \pm$ $7.9 \%$ to $18.79 \pm 8.5 \%$ in males and from $19.2 \pm 7.2 \%$ to $21.48 \pm 7.0 \%$ in females. Waist circumference in males ranged from $58.4 \pm 8.02 \mathrm{~cm}$ to $68.18 \pm 9.57 \mathrm{~cm}$ (difference of $9.78 \mathrm{~cm}$ ) and from $58.5 \pm 8.7 \mathrm{~cm}$ to 67.23 $\pm 9.1 \mathrm{~cm}$ (difference of $8.78 \mathrm{~cm}$ ) in females.

The proportion of six- and 12-year-old boys with overweight was 11.2 and $9 \%$ and with obesity, 14.7 and $15 \%$, respectively. The proportion of six and 12-yearold girls who had overweight was 8.2 and $9.1 \%$, whereas 21.7 and $13.3 \%$ had obesity, respectively.

Height average difference in Ponte al 100 school-age boys when making the comparison with Dr. Ramos-Galván charts (Fig. 2A) was non-existent, $-0.02 \mathrm{~m}(-0.04,0.01$, $p=0.16)$; when the comparison was made with the CDC charts (Fig. 2B), the difference was $-0.05 \mathrm{~m}(-0.07,-0.03$, $\mathrm{p}<0.0001)$. For the girls, in the comparison with Dr. Ramos-Galván charts (Fig. 2C), the difference was, again, practically non-existent, although statistically significant: $-0.02 \mathrm{~m}(-0.04,0.00, p=0.02)$; in comparison with the CDC charts (Fig. 2D), the difference was $-0.05 \mathrm{~m}$ $(-0.07,-0.04, p=0.00001)$.

\section{Discussion}

The weight and height progression profile of a population depends on various factors, both genetic and

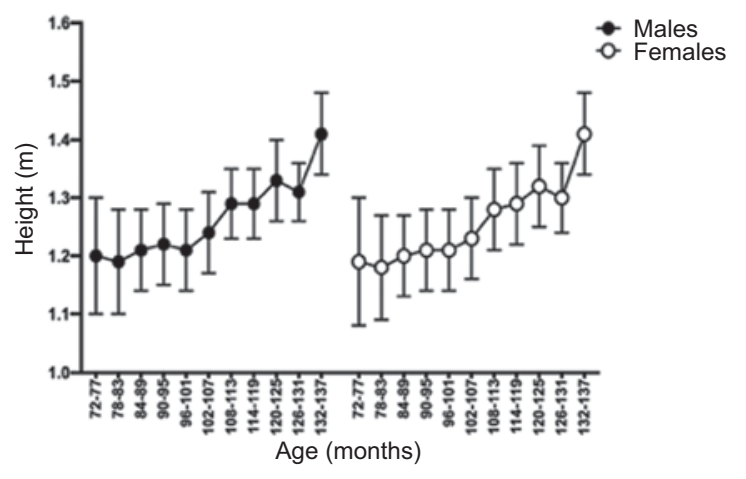

Figure 1. Height measured in 43,670 boys and 44,103 girls. Height increase between 6 and 12 years of age was $21 \mathrm{~cm}$ in males $(1.20 \pm$ 0.10 to $1.41 \pm 0.07)$ and $22 \mathrm{~cm}$ in females $(1.19 \pm 0.11$ to $1.41 \pm 0.07)$.

environmental. ${ }^{15}$ At an individual level, height is genetically predetermined by biological systems functionality and integrity; ${ }^{15}$ however, these systems depend on the nutritional and general health status of the individual. The secular height increase is a phenomenon where average height of a population increases depending on demographic and epidemiological transitions, with this phenomenon being a reflection of better health, nutritional and socioeconomic conditions. ${ }^{16,17}$ Secular height increase during the $20^{\text {th }}$ century is well documented in European and United States populations. ${ }^{16-18}$ In Mexico, this phenomenon has been identified and characterized in urban and rural populations of Oaxaca. ${ }^{19,20}$

Our results at the beginning of school age (six years) show an increase of $4.5 \mathrm{~cm}$ in males (120 versus $115.5 \mathrm{~cm}$ ) and $4 \mathrm{~cm}$ in females (115 versus $119 \mathrm{~cm}$ ), which are larger than those referred to by the CDC charts of year 2000. ${ }^{21}$ After seven years of age, these differences disappear: height is $5 \mathrm{~cm}$ larger in those referred by the CDC and practically the same to that referred by Dr. Ramos-Galván, ${ }^{8}$ an thus there seems to be no significant gain over the last 40 years. From the point of view of height at seven years of age, our results are similar to those reported in other Latin American countries such as Colombia, ${ }^{6}$ Venezuela ${ }^{22}$ and Argentina, ${ }^{23}$ although at 10 years of age in females and at 12 years in males it was lower. However, it should be noted that these series, particularly the Colombian, include only individuals of a high socioeconomic class, which undoubtedly influences on population growth and development.

The results above suggest that the height development pattern in healthy Mexican children is similar across the population and that it has not changed over 
Table 1. Growth charts for school-age boys

\begin{tabular}{|c|c|c|c|c|c|c|c|c|c|}
\hline $\begin{array}{l}\text { Age, years } \\
\text { (range in } \\
\text { months) }\end{array}$ & $\begin{array}{c}\text { Ponte al } \\
100^{*} \\
\text { Mean } \pm \text { SD } \\
\text { (range) }\end{array}$ & $\begin{array}{l}\text { Ramos- } \\
\text { Galván* } \\
\text { Mean } \pm \text { SD } \\
\text { (n) }\end{array}$ & $\begin{array}{c}\text { CDC* }^{*} \\
\text { Mean } \pm \text { SD } \\
\text { (n) }\end{array}$ & $\begin{array}{l}\text { Weight, kg } \\
\text { Mean } \pm \text { SD } \\
\text { (range) }\end{array}$ & $\begin{array}{c}\text { BMI, } \mathrm{kg} / \mathrm{m}^{2} \\
\text { Mean } \pm \text { SD } \\
\text { (range) }\end{array}$ & $\begin{array}{c}\% \text { fat } \\
\text { Mean } \pm \text { SD }\end{array}$ & $\begin{array}{c}\text { Waist } \\
\text { circumference, } \\
\text { cm Mean } \pm \text { SD }\end{array}$ & $\begin{array}{l}\text { Overweight, } \\
\text { CDC \% }\end{array}$ & $\begin{array}{l}\text { Obesity, } \\
\text { CDC \% }\end{array}$ \\
\hline $\begin{array}{l}6 \text { years } \\
(n=525) \\
(72-77)\end{array}$ & $\begin{array}{l}1.20 \pm 0.10 \\
(0.96-1.48)\end{array}$ & $\begin{array}{c}1.14 \pm 0.04 \\
(60)\end{array}$ & $\begin{array}{c}1.17 \pm 0.05 \\
(700)\end{array}$ & $\begin{array}{c}25.62 \pm 6.87 \\
\quad(16-47)\end{array}$ & $\begin{array}{l}17.1 \pm 2.7 \\
(9.6-31.5)\end{array}$ & $17.05 \pm 8.2$ & $58.41 \pm 8.02$ & 11.2 & 14.7 \\
\hline $\begin{array}{l}6 \text { years and } \\
6 \text { months } \\
(n=1111) \\
(78-83)\end{array}$ & $\begin{array}{l}1.19 \pm 0.09 \\
(0.97-1.48)\end{array}$ & $\begin{array}{c}1.14 \pm 0.04 \\
(60)\end{array}$ & $\begin{array}{c}1.20 \pm 0.05 \\
(700)\end{array}$ & $\begin{array}{c}24.25 \pm 5.87 \\
(15.2-47)\end{array}$ & $\begin{array}{c}16.8 \pm 2.9 \\
(9.7-47)\end{array}$ & $16.88 \pm 7.9$ & $56.91 \pm 7.19$ & 9.7 & 8.8 \\
\hline $\begin{array}{l}7 \text { years } \\
(n=2538) \\
(84-89)\end{array}$ & $\begin{array}{l}1.21 \pm 0.07 \\
(1.05-1.40)\end{array}$ & $\begin{array}{c}1.20 \pm 0.04 \\
(57)\end{array}$ & $\begin{array}{c}1.23 \pm 0.05 \\
(700)\end{array}$ & $\begin{array}{c}24.43 \pm 4.71 \\
(15.2-38.9)\end{array}$ & $\begin{array}{l}16.5 \pm 2.3 \\
(8.5-32.2)\end{array}$ & $18.79 \pm 8.5$ & $57.42 \pm 7.26$ & 9.0 & 14.6 \\
\hline $\begin{array}{l}7 \text { years and } \\
6 \text { months } \\
(n=4350) \\
(90-95)\end{array}$ & $\begin{array}{l}1.22 \pm 0.07 \\
(1.05-1.40)\end{array}$ & $\begin{array}{c}1.23 \pm 0.05 \\
(57)\end{array}$ & $\begin{array}{c}1.26 \pm 0.05 \\
(700)\end{array}$ & $\begin{array}{c}24.74 \pm 4.78 \\
(15.1-38.9)\end{array}$ & $\begin{array}{l}16.4 \pm 2.2 \\
(8.1-27.9)\end{array}$ & $18.45 \pm 8.7$ & $57.61 \pm 7.47$ & 9.1 & 13.8 \\
\hline $\begin{array}{l}8 \text { years } \\
(n=7071) \\
(96-101)\end{array}$ & $\begin{array}{l}1.21 \pm 0.07 \\
(1.07-1.40)\end{array}$ & $\begin{array}{c}1.26 \pm 0.05 \\
(55)\end{array}$ & $\begin{array}{c}1.29 \pm 0.06 \\
(700)\end{array}$ & $\begin{array}{c}24.46 \pm 4.89 \\
(15.2-38.7)\end{array}$ & $\begin{array}{l}16.4 \pm 2.3 \\
(8.6-30.3)\end{array}$ & $17.28 \pm 8.5$ & $57.41 \pm 7.04$ & 9.3 & 11.5 \\
\hline $\begin{array}{l}8 \text { years and } \\
6 \text { months } \\
(n=4339) \\
(102-107)\end{array}$ & $\begin{array}{l}1.24 \pm 0.07 \\
(1.07-1.40)\end{array}$ & $\begin{array}{c}1.28 \pm 0.05 \\
(55)\end{array}$ & $\begin{array}{c}1.32 \pm 0.06 \\
(700)\end{array}$ & $\begin{array}{c}25.24 \pm 4.89 \\
(15.9-38.7)\end{array}$ & $\begin{array}{l}16.3 \pm 2.2 \\
(8.1-28.9)\end{array}$ & $16.71 \pm 8.5$ & $57.90 \pm 7.05$ & 9.2 & 13.4 \\
\hline $\begin{array}{l}9 \text { years } \\
(n=5166) \\
(108-113)\end{array}$ & $\begin{array}{l}1.29 \pm 0.06 \\
(1.01-1.45)\end{array}$ & $\begin{array}{c}1.33 \pm 0.05 \\
(52)\end{array}$ & $\begin{array}{c}1.35 \pm 0.05 \\
(700)\end{array}$ & $\begin{array}{c}28.55 \pm 5.66 \\
(17-43.3)\end{array}$ & $\begin{array}{c}17.1 \pm 2.6 \\
(9.4-33)\end{array}$ & $17.33 \pm 8.7$ & $60.34 \pm 7.77$ & 9.1 & 13.6 \\
\hline $\begin{array}{l}9 \text { years and } \\
6 \text { months } \\
(n=2799) \\
(114-119)\end{array}$ & $\begin{array}{l}1.29 \pm 0.06 \\
(1.14-1.45)\end{array}$ & $\begin{array}{c}1.33 \pm 0.05 \\
(52)\end{array}$ & $\begin{array}{c}1.37 \pm 0.07 \\
(700)\end{array}$ & $\begin{array}{c}28.1 \pm 5.3 \\
(16.3-43.3)\end{array}$ & $\begin{array}{l}16.6 \pm 2.2 \\
(8.5-31.7)\end{array}$ & $16.51 \pm 8.5$ & $59.83 \pm 7.04$ & 9.2 & 12.2 \\
\hline $\begin{array}{l}10 \text { years } \\
(n=6799) \\
(120-125)\end{array}$ & $\begin{array}{l}1.33 \pm 0.07 \\
(1.17-1.49)\end{array}$ & $\begin{array}{c}1.36 \pm 0.06 \\
(40)\end{array}$ & $\begin{array}{c}1.40 \pm 0.07 \\
(700)\end{array}$ & $\begin{array}{c}31.78 \pm 6.82 \\
(17.3-48.9)\end{array}$ & $\begin{array}{l}17.8 \pm 2.9 \\
(9.0-33.9)\end{array}$ & $17.85 \pm 8.6$ & $62.88 \pm 8.49$ & 9.0 & 13.9 \\
\hline $\begin{array}{l}10 \text { years } \\
\text { and } \\
6 \text { months } \\
(n=1179) \\
(126-131)\end{array}$ & $\begin{array}{l}1.31 \pm 0.05 \\
(1.17-1.45)\end{array}$ & $\begin{array}{c}1.36 \pm 0.06 \\
(40)\end{array}$ & $\begin{array}{c}1.42 \pm 0.07 \\
(700)\end{array}$ & $\begin{array}{c}29.13 \pm 4.82 \\
(18-47)\end{array}$ & $\begin{array}{l}16.9 \pm 2.4 \\
(9.8-28.2)\end{array}$ & $16.03 \pm 7.9$ & $59.97 \pm 6.08$ & 9.8 & 7.6 \\
\hline $\begin{array}{l}11 \text { years } \\
(n=7793) \\
(132-137)\end{array}$ & $\begin{array}{l}1.41 \pm 0.07 \\
(1.25-1.56)\end{array}$ & $\begin{array}{c}1.41 \pm 0.06 \\
(34)\end{array}$ & $\begin{array}{c}1.45 \pm 0.07 \\
(700)\end{array}$ & $\begin{array}{c}35.48 \pm 7.33 \\
(19.5-54.6)\end{array}$ & $\begin{array}{l}17.9 \pm 2.8 \\
(9.1-31.2)\end{array}$ & $17.58 \pm 7.9$ & $68.18 \pm 9.57$ & 9.0 & 15 \\
\hline
\end{tabular}

*Height, $\mathrm{m} . \mathrm{SD}=$ estimated standard deviation, $\mathrm{CDC}=$ Centers for Disease Control.

the last 40 years, either in Mexico City, as shown by Dr. Ramos-Galván charts more than 40 years ago, or in the rest of the country, as shown by our results, in which urban, suburban and rural populations are represented. Dr. Ramos-Galván charts included predominantly healthy children from Mexico City, which proved to be an adequate sample, since at that time it was the area of the highest socioeconomic development in the country, which guaranteed good nutrition and showed full height development. Forty years later, we can observe that average height development has reached its peak as a result of an improvement in access to food and health services throughout the Mexican territory. ${ }^{24,25}$ 
Ferreira-Hermosillo A, et al.: Weight and height in Mexican children between 6 and 12 years of age

Table 2. Growth charts for school-age girls

\begin{tabular}{|c|c|c|c|c|c|c|c|c|c|}
\hline $\begin{array}{l}\text { Age, years } \\
\text { (range in } \\
\text { months) }\end{array}$ & $\begin{array}{c}\text { Ponte al } 100 \\
\text { Mean } \pm \text { SD } \\
\text { (range) }\end{array}$ & $\begin{array}{l}\text { Ramos- } \\
\text { Galván* } \\
\text { Mean } \pm \text { SD } \\
\text { (N) }\end{array}$ & $\begin{array}{c}\text { CDC* }^{*} \\
\text { Mean } \pm \text { SD } \\
(n)\end{array}$ & $\begin{array}{l}\text { Weight, kg } \\
\text { Average } \\
\text { (range) }\end{array}$ & $\begin{array}{c}\text { BMl, kg/m² } \\
\text { Average } \\
\text { (range) }\end{array}$ & $\begin{array}{c}\% \text { fat } \\
\text { Mean } \pm \text { SD }\end{array}$ & $\begin{array}{c}\text { Waist } \\
\text { circumference, } \\
\text { cm Mean } \pm \text { SD }\end{array}$ & $\begin{array}{l}\text { Overweight } \\
\text { (CDC) \% }\end{array}$ & $\begin{array}{l}\text { Obesity } \\
\text { (CDC) \% }\end{array}$ \\
\hline $\begin{array}{l}6 \text { years } \\
(n=475) \\
(72-77)\end{array}$ & $1.19 \pm 0.11$ & $\begin{array}{c}1.14 \pm 0.04 \\
(118)\end{array}$ & $\begin{array}{c}1.16 \pm 0.07 \\
(700)\end{array}$ & $\begin{array}{c}25.42 \pm 6.63 \\
\quad(16-48)\end{array}$ & $\begin{array}{l}17.4 \pm 3.4 \\
(7.2-42.4)\end{array}$ & $19.5 \pm 7.9$ & $58.5 \pm 8.7$ & 8.2 & 21.7 \\
\hline $\begin{array}{l}6 \text { years and } \\
6 \text { months } \\
(n=1124) \\
(78-83)\end{array}$ & $\begin{array}{l}1.18 \pm 0.09 \\
(0.98-1.49)\end{array}$ & $\begin{array}{c}1.17 \pm 0.05 \\
(118)\end{array}$ & $\begin{array}{c}1.20 \pm 0.05 \\
(700)\end{array}$ & $\begin{array}{c}24.05 \pm 5.95 \\
\quad(15-48)\end{array}$ & $\begin{array}{c}16.8 \pm 3 \\
(8.6-35.1)\end{array}$ & $19.2 \pm 7.2$ & $56.41 \pm 7.24$ & 9.4 & 9.6 \\
\hline $\begin{array}{l}7 \text { years } \\
(n=2473) \\
(84-89)\end{array}$ & $\begin{array}{l}1.20 \pm 0.07 \\
(1.04-1.40)\end{array}$ & $\begin{array}{c}1.20 \pm 0.05 \\
(130)\end{array}$ & $\begin{array}{c}1.23 \pm 0.05 \\
(700)\end{array}$ & $\begin{array}{c}24.01 \pm 4.84 \\
(15.3-39)\end{array}$ & $\begin{array}{l}16.4 \pm 2.5 \\
(8.8-31.4)\end{array}$ & $21.11 \pm 7.3$ & $56.92 \pm 7.17$ & 9.1 & 13.5 \\
\hline $\begin{array}{l}7 \text { years and } \\
6 \text { months } \\
(n=4362) \\
(90-95)\end{array}$ & $\begin{array}{l}1.21 \pm 0.07 \\
(1.04-1.40)\end{array}$ & $\begin{array}{c}1.22 \pm 0.05 \\
(130)\end{array}$ & $\begin{array}{c}1.26 \pm 0.06 \\
(700)\end{array}$ & $\begin{array}{c}24.54 \pm 5 \\
(15.1-39)\end{array}$ & $\begin{array}{l}16.5 \pm 2.4 \\
(9.6-35.1)\end{array}$ & $20.99 \pm 7.3$ & $57.47 \pm 7.58$ & 7.2 & 14.7 \\
\hline $\begin{array}{l}8 \text { years } \\
(n=6984) \\
(96-101)\end{array}$ & $\begin{array}{l}1.21 \pm 0.07 \\
(1.06-1.39)\end{array}$ & $\begin{array}{c}1.25 \pm 0.05 \\
(152)\end{array}$ & $\begin{array}{c}1.29 \pm 0.06 \\
(700)\end{array}$ & $\begin{array}{l}24.07 \pm 4.9 \\
(15.5-38.2)\end{array}$ & $\begin{array}{l}16.3 \pm 2.3 \\
(9.8-29.7)\end{array}$ & $19.96 \pm 7.0$ & $56.96 \pm 7.10$ & 9.2 & 11.8 \\
\hline $\begin{array}{l}8 \text { years and } \\
6 \text { months } \\
(n=4261) \\
(102-107)\end{array}$ & $\begin{array}{l}1.23 \pm 0.07 \\
(1.06-1.09)\end{array}$ & $\begin{array}{c}1.28 \pm 0.05 \\
(152)\end{array}$ & $\begin{array}{c}1.31 \pm 0.06 \\
(700)\end{array}$ & $\begin{array}{c}24.84 \pm 4.97 \\
(16-38.2)\end{array}$ & $\begin{array}{l}16.3 \pm 2.3 \\
(9.9-32.5)\end{array}$ & $19.77 \pm 7.0$ & $57.62 \pm 7.08$ & 9.2 & 12.9 \\
\hline $\begin{array}{l}9 \text { years } \\
(n=5259) \\
(108-113)\end{array}$ & $\begin{array}{l}1.28 \pm 0.07 \\
(1.13-1.53)\end{array}$ & $\begin{array}{c}1.30 \pm 0.05 \\
(153)\end{array}$ & $\begin{array}{c}1.34 \pm 0.06 \\
(700)\end{array}$ & $\begin{array}{c}28.09 \pm 5.58 \\
(17-42.7)\end{array}$ & $\begin{array}{l}17.0 \pm 2.5 \\
(8.8-32.8)\end{array}$ & $20.86 \pm 7.2$ & $59.99 \pm 7.48$ & 9.2 & 12.4 \\
\hline $\begin{array}{l}9 \text { years and } \\
6 \text { months } \\
(n=2918) \\
(114-119)\end{array}$ & $\begin{array}{l}1.29 \pm 0.07 \\
(1.13-1.53)\end{array}$ & $\begin{array}{c}1.33 \pm 0.06 \\
(153)\end{array}$ & $\begin{array}{c}1.36 \pm 0.06 \\
(700)\end{array}$ & $\begin{array}{c}27.86 \pm 5.31 \\
(17-42.7)\end{array}$ & $\begin{array}{l}16.6 \pm 2.1 \\
(8.8-29.9)\end{array}$ & $20.32 \pm 7.1$ & $59.43 \pm 7.06$ & 9.3 & 10.4 \\
\hline $\begin{array}{l}10 \text { years } \\
(n=6850) \\
(120-125)\end{array}$ & $\begin{array}{l}1.32 \pm 0.07 \\
(1.16-1.48)\end{array}$ & $\begin{array}{c}1.36 \pm 0.06 \\
(143)\end{array}$ & $\begin{array}{c}1.39 \pm 0.07 \\
(700)\end{array}$ & $\begin{array}{c}31.27 \pm 6.92 \\
(17.2-48.3)\end{array}$ & $\begin{array}{l}17.5 \pm 2.8 \\
(8.9-31.4)\end{array}$ & $21.48 \pm 7.0$ & $62.08 \pm 8.2$ & 9.0 & 15.0 \\
\hline $\begin{array}{l}10 \text { years and } \\
6 \text { months } \\
(n=1308) \\
(126-131)\end{array}$ & $\begin{array}{l}1.30 \pm 0.06 \\
(1.16-1.48)\end{array}$ & $\begin{array}{c}1.39 \pm 0.06 \\
(143)\end{array}$ & $\begin{array}{c}1.42 \pm 0.09 \\
(700)\end{array}$ & $\begin{array}{c}29.08 \pm 5.08 \\
(18-48)\end{array}$ & $\begin{array}{l}16.9 \pm 2.6 \\
(9.1-32.1)\end{array}$ & $19.7 \pm 6.4$ & $59.78 \pm 6.5$ & 9.7 & 8.0 \\
\hline $\begin{array}{l}11 \text { years } \\
(n=8089) \\
(132-137)\end{array}$ & $\begin{array}{l}1.41 \pm 0.07 \\
(1.23-1.57)\end{array}$ & $\begin{array}{c}1.43 \pm 0.07 \\
(141)\end{array}$ & $\begin{array}{c}1.45 \pm 0.07 \\
(700)\end{array}$ & $\begin{array}{c}35.47 \pm 7.56 \\
(20-54.3)\end{array}$ & $\begin{array}{l}17.8 \pm 2.8 \\
(9.9-32.7)\end{array}$ & $20.33 \pm 7.0$ & $67.23 \pm 9.1$ & 9.1 & 13.3 \\
\hline
\end{tabular}

*Height, $\mathrm{cm} . \mathrm{SD}$ = estimated standard deviation, $\mathrm{CDC}=$ Centersi for Disease Control.

It is important to highlight that our study population represents healthy school-age children from public schools across the entire country. ${ }^{13}$ The prevalence of obesity found in this population at different ages (from 7.6 to $15 \%$ in boys and from 8 to $21 \%$ in girls) is similar to the prevalence reported in Halfway ENSANUT 2016, which clearly indicates the national representativeness of our study population. ${ }^{26}$ The epidemiological transition shows the population shift from undernutrition to an adequate weight for age and height, but it is inevitably moving towards overweight and obesity. As the country's nutritional conditions continue to improve, a reduction in the incidence of overweight and obesity is expected to be observed as a result of an improvement in access to higher quality food, 


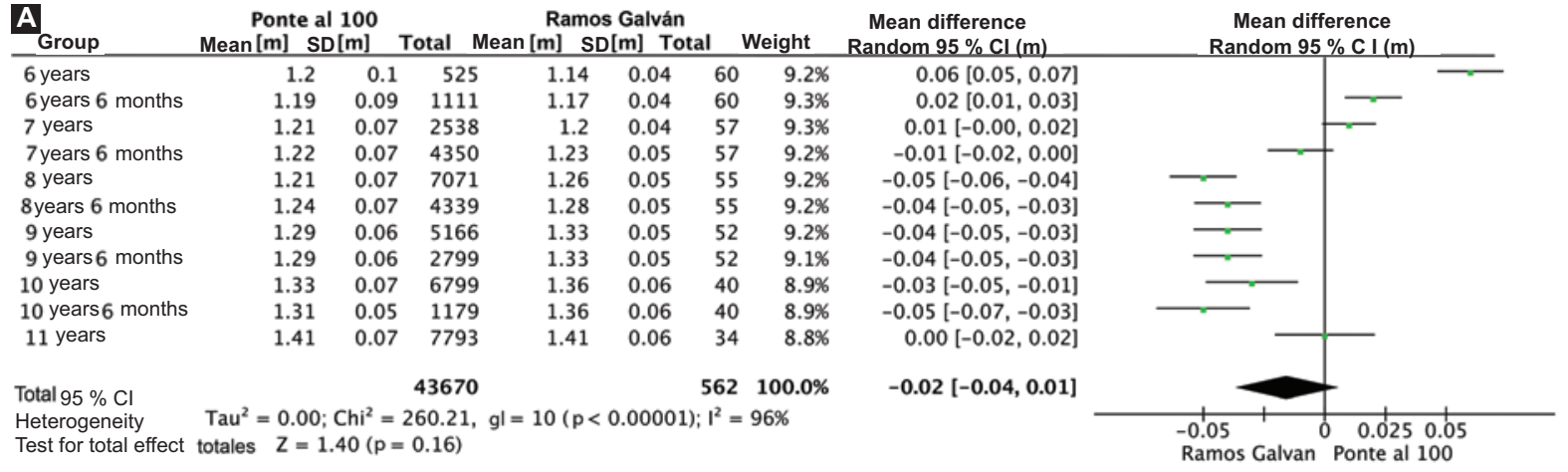

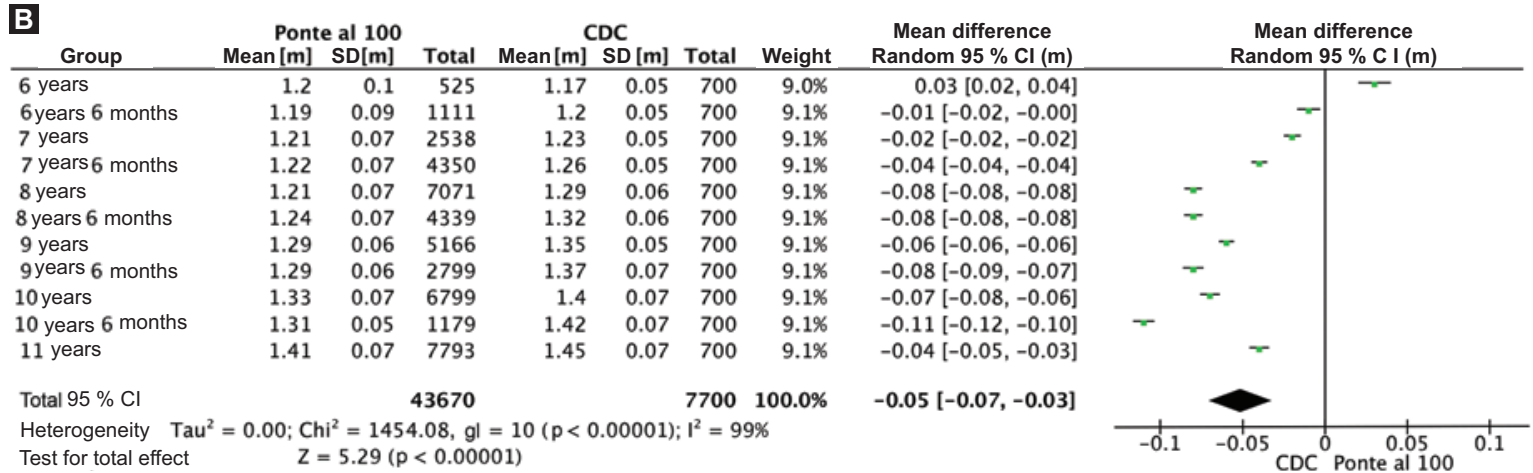

C

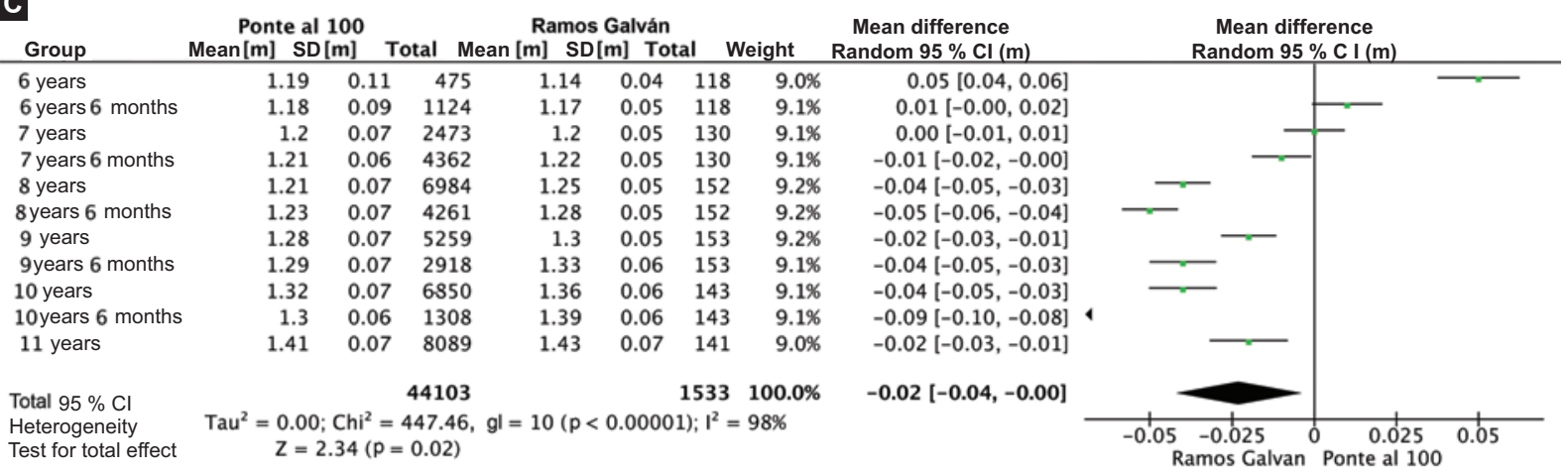

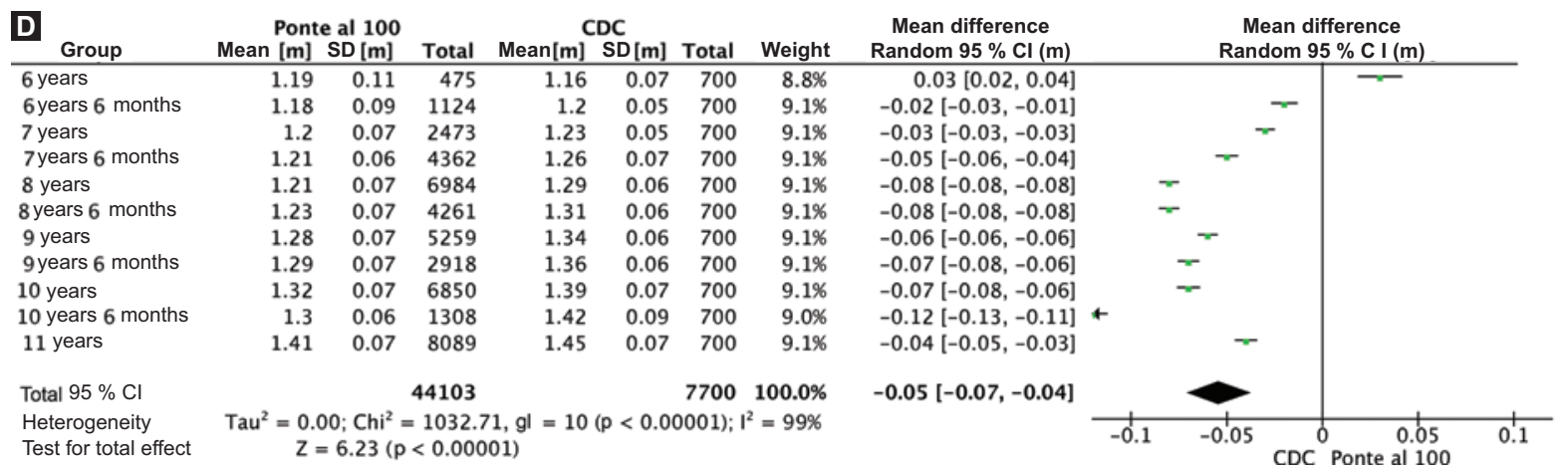

Figure 2. Average height difference of school-age boys and girls enrolled in the Ponte al 100 program. A) Boys, $-0.02 m(-0.04,0.01, p=0.16)$ in comparison with Dr. Ramos-Galván charts. B) Boys, $-0.05 m(-0.07,-0.03, p<0.0001)$ in comparison with the CDC charts. C) Girls, $-0.02 \mathrm{~m}(-0.04$, $0.00, p=0.02)$ in comparison with Dr. Ramos-Galván charts, $D)$ Girls, $-0.05 m(-0.07,-0.04, p=0.00001)$ in comparison with the CDC charts.

accompanied by better physical activity habits, which are actions that are promoted by programs such as Ponte al $100 .^{13,27}$
The limitations of our analysis include a possible variability in measurements as a result of the number of evaluators, although all had a similar level of 
education and were standardized on the techniques. The advantages include the sample size, more than 87,000 boys and girls, which is why this is the largest anthropometric study in the world, $5,6,28-31$ in addition to including all geographical areas and socioeconomic strata of Mexico.

Although the secular height increase over the centuries is a documented phenomenon, ${ }^{17}$ in our study we failed to identify it. One explanation is that, as a species, we have reached maximum height, whose average remains stable due to access to food and health services optimization. Alternatively, there is the possibility that longer follow-up time is required to identify a true secular height increase.

There are multiple questions to be answered, including assessing if growth is more accelerated in obese children. The challenge as a country is and will continue to be, in the next few years, access to higher quality food and the development of physical activity habits that lead to an improvement in functional capacity and quality of life. ${ }^{32-34}$

\section{References}

1. Bann D, Johnson W, Li L, Kuh D, Hardy R. Socioeconomic inequalities in childhood and adolescent body-mass index, weight, and height from 1953 to 2015: an analysis of four longitudinal, observational, British birth cohort studies. Lancet Public Health. 2018;3:e194-e203.

2. Gonçalves H, Barros FC, Buffarini R, Horta BL, Menezes AMB Barros AJD, et al. Infant nutrition and growth: trends and inequalities in four population-based birth cohorts in Pelotas, Brazil, 1982-2015. Int J Epidemiol. 2019;48:i80-i88.

3. Manios Y, Karatzi K, Moschonis G, loannou G, Androutsos O, Lionis C et al. Lifestyle, anthropometric, socio-demographic and perinatal correlates of early adolescence hypertension: The Healthy Growth Study. Nutr Metab Cardiovasc Dis. 2019;29:159-169.

4. Loret de Mola C, Quispe R, Valle GA, Poterico JA. Nutritional transition in children under five years and women of reproductive age: a 15-years trend analysis in Peru. PLoS One. 2014:9:e92550.

5. Cardoso HF, Padez C. Changes in height, weight, BMI and in the prevalence of obesity among 9-to-11-year-old affluent Portuguese schoolboys, between 1960 and 2000. Ann Hum Biol. 2008:35:624-638.

6. Durán P, Merker A, Briceño G, Colón E, Line D, Abad V, et al. Colombian reference growth curves for height, weight, body mass index and head circumference. Acta Pediatr. 2016;105:e116-e125.

7. Bustamante A, Freitas D, Pan H, Katzmarzyk PT, Maia J. Centile curves and reference values for height, body mass, body mass index and wais circumference of Peruvian children and adolescents. Int J Environ Res Public Health. 2015:12:2905-2922.

8. Ramos-Galván R. Pediatric somatometry. Semilongituginal study of children in Mexico City. Arch Invest Med (Mex). 1975;6:83-396.

9. Erdei G, Bakacs M, Illés É, Nagy B, Kaposvári C, Mák E, et al. Substantial variation across geographic regions in the obesity prevalence among 6-8 years old Hungarian children (COSI Hungary 2016). BMC Public Health. 2018;18:611.

10. Márquez-Gonzáles H, García-Sámano VM, Caltenco-Serrano ML, García-Villegas EA, Márquez-Flores $H$, Billa-Romero AR. Clasificación y evaluación de la desnutrición en el paciente pediátrico. El Residente. 2010;7:59-69
11. Rito A, Wijnhoven TM, Rutter H, Carvalho MA, Paixão E, Ramos C, et al. Prevalence of obesity among Portuguese children (6-8 years old) using three definition criteria: COSI Portugal, 2008. Pediatr Obes. 2012;7:413-422.

12. Brito-Zurita OR, López-Leal J, Exiga-González EB, Armenta-Llanes O, Jorge-Plascencia B, Domínguez-Banda A, et al. Medidas antropométricas. en la población infantil urbana de 6 a 12 años del noroeste de México. Rev Med Inst Mex Seguro Soc. 2014;52:S34-S41.

13. Palacios-Butchart JJ, Herrera-Navarro JM, Melgar V, Rangel MJ, Ferreira-Hermosillo A, Roy-García I, et al. Ponte al 100: a nationwide exercise and nutrition intervention program in Mexican children and adolescents: study population and methodology. Rev Mex Endocrinol Metab Nutr. 2016:3:175-181.

14. Rivas-Ruiz R, Castelán-Martínez OD, Pérez-Rodríguez $M$, Palacios-Cruz L, Noyola-Castillo ME, Talavera JO. Clinical research XXIII. From clinical judgment to meta-analyses. Rev Med Inst Mex Seguro Soc. 2014;52:558-65

15. Benyi E, Sävendahl L. The physiology of childhood growth: hormonal regulation. Horm Res Paediatr. 2017;88:6-14.

16. Cole TJ. Secular trends in growth. Proc Nutr Soc. 2000;59:317-324

17. Fudvoye J, Parent AS. Secular trends in growth. Ann Endocrinol (Paris). 2017;78:88-91.

18. Meredith HV. Findings from Asia, Australia, Europe and North America on secular change in mean height of children youths and young adults. Am J Phys Anthropol. 1976;44:315-325

19. Malina RM Little BB, Peña-Reyes ME. Secular trends are associated with the demographic and epidemiologic transitions in an indigenous community in Oaxaca, Southern Mexico. Am J Phys Anthropol. 2018;165:47-64.

20. Malina RM, Peña-Reyes ME, Little BB. Secular change in the growth status of urban and rural school children aged 6-13 years in Oaxaca, southern Mexico. Ann Hum Biol. 2008;35:475-489.

21. Kuczmarski RJ, Ogden CL, Guo SS, Grummer-Strawn LM, Flegal KM, Mei Z, et al. 2000 CDC growth charts for the United States: methods and development. Vital Health Stat 11. 2002;246:1-190.

22. López-Blanco M, Landaeta-Jiménez M, Izagirre-Espinoza I, Macías-Tomei C. Estudio nacional de crecimiento y desarrollo humano en la República de Venezuela. Venezuela: Escuela Técnica Salesiana; 1996.

23. Lejarraga $\mathrm{H}$, Orfila $\mathrm{G}$. Weight and height standards for Argentinian girls and boys from birth to maturity. Arch Argent Pediatr. 1987;85:209-22.

24. Turnbull B, Gordon SF, Martínez-Andrade GO, González-Unzaga M. Childhood obesity in Mexico: a critical analysis of the environmental factors, behaviors and discourses contributing to the epidemic. Health Psychol Open. 2019;6:2055102919849406.

25. Vásquez-Garibay EM, Miranda-Ríos L, Romero-Velarde E, Nuño-Cosío ME, Campos-Barrera L, Nápoles-Rodríguez F, et al. Stunting, overweight and obesity during the nutrition transition in schoolchildren of Arandas, Jalisco, Mexico. Rev Med Inst Mex Seguro Soc. 2018:56:6-11.

26. Encuesta Nacional de Salud y Nutrición de Medio Camino 2016. Informe final de resultados. México: Instituto Nacional de Salud Pública; 2016.

27. Urquía-Fernández N. La seguridad alimentaria en México. Salud Publica Mex. 2014:56:S92-S98.

28. Orden AB, Torres MF, Castro L, Cesani MF, Luis MA, Quintero FA, et al. Physical growth in schoolchildren from Argentina: comparison with Argentinean and CDC/NCHs growth references. Am J Hum Biol. 2009;21:312-318.

29. Garzón M, Papoila AL, Alves M, Pereira-da-Silva L. Comparison of growth curve estimates of infants in São Tomé Island, Africa, with the WHO growth standards: a birth cohort study. Int J Environ Res Public Health. 2019:16:E1693.

30. El Mouzan MI, Shaffi A, Salloum AA, Alqurashi MM, Herbish AA, Omer AA. Z-score growth reference data for Saudi preschool children. Ann Saudi Med. 2017:37:10-15

31. Neyzi O, Bundak R, Gökçay G, Günöz H, Furman A, Darendeliler F, et al. Reference Values for weight, height, head circumference, and body mass index in Turkish children. J Clin Res Pediatr Endocrinol. 2015;7:280-293.

32. Wen CP, Wai JP, Tsai MK, Yang YC, Cheng TY, Lee MC, et al. Minimum amount of physical activity for reduced mortality and extended life expectancy: a prospective cohort study. Lancet. 2011;378:1244-1253.

33. Redondo-Tébar A, Ruíz-Hermosa A, Martínez-Vizcaíno V, Cobo-Cuenca Al, Bermejo-Cantarero A, Cavero-Redondo I, et al. Associations between health-related quality of life and physical fitness in 4-7-year-old Spanish children: the MOVIKIDS study. Qual Life Res. 2019;28:1751-1759.

34. Oja P, Kelly P, Pedisic Z, Titze S, Bauman A, Foster C, et al. Associations of specific types of sports and exercise with all-cause and cardiovascular-disease mortality: a cohort study of 80306 British adults. $\mathrm{Br} \mathrm{J}$ Sports Med. 2017:51:812-817. 